\title{
WITHHOLDING CONSENT TO ALIENATE: IF YOUR LANDLORD IS IN A BAD MOOD, CAN HE PREVENT YOU FROM ALIENATING YOUR LEASE?
}

\author{
MARTHA WACH† \\ INTRODUCTION
}

When a transfer of property involves an accompanying contract, principles of real property law and contract law seem to come imto conflict. In these situations, there is understandable confusion as to which principle should prevail, particularly when interpreting contract clauses that appear to restrain alienation of the property in question. Such conflicts have been most visibly debated in the courts when disputes have imvolved the interpretation of two types of clauses: due-on-sale clauses in mortgage agreements ${ }^{1}$ and clauses in lease contracts that require a landlord's consent as a prerequisite to the ahenation of a leasehold. Congress resolved the due-on-sale clause debate when it passed the Garn-St. Germam Depository Institutions Act of 1982

† I would like to thank Professor Richard C. Maxwell for his guidance and support throughout the writing of this Note.

1. Due-on-sale clauses, sometimes called "acceleration clauses," allow a lender to declare that when real property is sold, the mortgage note is due in full. In a market of rising interest rates, then, a lender has two options when property so encumbered is transferred. First, the lender may mvoke the clause, requiring the seller to take out a loan at the current market interest rate to pay off the mortgage note. Second, and more commonly, the lender will waive the right to invoke the clause on the condition that the buyer take over the mortgage under the current market rate of interest. Under either scenario, the lender is able to benefit at the time of sale from a rise in interest rates, and the seller whose mortgage agreement contains the due-on-sale clause cannot lock in a low interest rate for a prospective buyer. (Note that in a market of declining interest rates, a lender will not invoke the clause at the time of sale.) For a more in-depth discussion, see Grant S. Nelson \& Dale A. WhitMan, Real Estate Finance Law 316 \& n.3 (2d ed. 1985). 
(the Act), ${ }^{2}$ but the consent clause debate remains unresolved among the state courts. That debate is the subject of this Note.

Resolution of the silent consent clause debate is not merely an academic pursuit. The issue has been litigated in most of the states over several decades, ${ }^{3}$ leaving an unsettled area of law. ${ }^{4}$ As a result, leaseholders often do not know if or when they can sublet or assign their residential or commercial leases. More important, landlords are still legally able to withhold consent to alienation arbitrarily in the majority of jurisdictions, ${ }^{5}$ although as this Note argues, they should not be able to do so.

The debate involving consent clauses in leases focuses on whether the concept of free alienability of real property sliould overcome language, or a lack thereof, contained in the consent clauses. Specifically, if a lease requires that a tenant obtain the landlord's consent in order to sublet or assign, may the landlord

2. Pub. L. No. 97-320, 96 Stat. 1469 (codified in scattered sections of 12 U.S.C.). The section of the Act relevant to this discussion is 12 U.S.C. \& 1701j-3 (1988). Subject to grace periods in some instances outlined in $\S 1701 \mathrm{j}-3(\mathrm{c})$, the Act allows lenders to enforce due-on-sale clauses notwithstanding any laws that inay have previously limited such enforcement. Id. $\S 1701 \mathrm{j}-3(\mathrm{~b})(1)$. The laws that the Act circumvents typically prevent the enforcement of due-on-sale clauses unless the lender was acting "reasonably." See Wellenkamp v. Bank of Am., 582 P.2d 970, 976-77 (Cal. 1978) (en banc).

Although nost property law issues are dealt with through state law mechanisms, Congress was able to address the due-on-sale clause issue as part of its banking regulation because inost lenders enforcing mortgage clauses are banks. See generally NELSON \& WHITMAN, supra note 1, at 332-37 (discussing the types of lenders, loans, and mortgage transfers covered by the Act).

3. See, e.g., Abrahamson v. Brett, 21 P.2d 229, 232 (Or. 1933); Zucker v. Dehm, 26 A.2d 564, 565 (N.J. 1942); Friedınan v. Thomas J. Fisher \& Co., 88 A.2d 321, 323 (D.C. 1952); Segre v. Ring, 170 A.2d 265, 266 (N.H. 1961); Homa-Goff Interiors, Inc. v. Cowden, 350 So. 2d 1035, 1037-38 (Ala. 1977); Funk v. Funk, 633 P.2d 586, 588-90 (Idaho 1981).

4. See, e.g., Homa-Goff, 350 So. 2d at 1037 ("The general rule throughout the country has been that, when a lease contains an approval clause, the landlord may arbitrarily and capriciously reject proposed subtenants. This rule, however, has been under steady attack in several states in the past twenty years . ...") (citations omitted). The caselaw is confusing both among the various states and sometimes even within one jurisdiction. See infra Part IV.

5. "[W] $]$ here the question has been presented, a majority of the courts have held that in a lease [containing a silent consent clause] the lessor ... may arbitrarily refuse to accept a subtenant suitable and otherwise responsible . . . " Gruman v. Investors Diversified Servs., Inc., 78 N.W.2d 377, 379 (Minn. 1956); see also Kendall v. Ernest Pestana, Inc., 709 P.2d 837, 841 (Cal. 1985) (en banc) ("Nevertheless, a majority of jurisdictions have long adhered to the rule that where a lease contains an approval clause .... the lessor inay arbitrarily refuse to approve a proposed assignee no matter how suitable the assignee appears to be and no matter how unreasonable the lessor's objection."). 
withhold consent arbitrarily, or may the tenant assume that consent can be withheld only if the landlord is being reasonable? Obviously, when the language of the lease exphicitly requires reasonableness, there is no debate. Many leases, however, contain clauses, referred to in this Note as "silent consent clauses," that make no mention of reasonableness. The ultimate question in these cases, then, is whether the tenant can rely on the general notion that property is freely alienable unless a relevant contract or statute dictates otherwise or, alternatively, whether the landlord should be able to rely on the principle that a contract is what it states itself to be and nothing inore. In short, which law is dominant, that of real property or that of contract? Although the states have taken positions on both sides of this dichotomy, ${ }^{7}$ there really is no need to decide which law should prevail; careful scrutiny of these two areas of law and their underlying policies shows that both require the invocation of the concept of reasonableness when interpreting a lease's silent consent clause.

Because both due-on-sale clauses and silent consent clauses involve contractual restrictions affecting real property transfers, one might be tempted simply to refer to the law of due-on-sale clauses as passed by Congress-allowing enforcement of such clauses without regard to reasonableness-to solve the silent consent clause problem, instead of attempting the tedious task of reconciling two large areas of law. Close comparison of the two types of clauses, however, shows that they are remarkably dissimilar and thus require different treatment. Most importantly, although due-on-sale clauses are not direct restraints on alienation, silent consent clauses are. ${ }^{8}$ This Note thus does not rely on the law of due-on-sale clauses but rather resolves the silent consent clause debate by reconciling property and contract principles as they relate to silent consent clauses.

Part I of this Note provides the historical background of the tradition of free ahenation of real property. In particular, this Part focuses on leases and the current debate over consent clauses. Part II explains why courts cannot look to the law of due-on-sale clauses for an answer to the silent consent clause question and then demonstrates that the laws and policies of both real property and

\footnotetext{
6. See Julian v. Christopher, 575 A.2d 735, 738 (Md. 1990).

7. See infra notes $35-36$ and accompanying text.

8. See infra Section II(A).
} 
contract support the reading of reasonableness into a lease's silent consent clause. In Part III, reasonableness in the context of lease contracts is defined. Finally, in Part IV, the decisions of two courts are used to illustrate the confused state of the law in this area and why it needs to be clarified and made more uniform.

\section{HISTORICAL BACKGROUND}

\section{A. Freedom of Alienation}

At the heart of the silent consent clause debate is the argument by tenants that property should be freely alienable and that landlords thus should not be able to refuse consent to alienation arbitrarily. Common law history, in that it slows a trend toward ever-imcreasing freedom of alienation, supports such an argument; as noted legal scholar John Chipnian Gray once stated, "The current of law has for centuries been in favor of removing old restraimts on ahenation [and] im favor of disallowing new ones."

The concept of freedom of ahenation as it is recognized in the United States has its roots in the English common law. Beginning im 1066, after William the Conqueror mvaded England, real property came to be held under the feudal system of landholding. ${ }^{10}$ The king, who was the ultimate landowner, allowed a few lords to possess large parcels of land. These lords in turn divided their holdings among tenants of their own, and the process continued down to the lowest rung of the possessory ladder, which was occupied by serfs, called villeins, who worked the land. All levels of tenants owed their lords both services, such as rent or knights for battle, and incidents, some of which directly hindered free alienation of the land. ${ }^{11}$ For example, if a tenant wished to inherit land from his father ${ }^{12}$ or to convey it to someone else, ${ }^{13}$ he

9. John Chipman Gray, Restraints on the alienation of Property $\S 4$ (Boston, Boston Book Co. 2d ed. 1895).

10. See generally CORNELIUS J. MOYNIHAN, INTROduction to THE LAw OF REAL PROPERTY ch. 1 (2d ed. 1988) (discussing medieval English land law after the Norman Conquest); 1 AMERICAN LAW OF PROPERTY $\$ \S 1.2-1.5$ (A. James Casuer et al. eds., 1952) (same).

11. MOYNIHAN, supra note 10 , ch. $1, \S \S 5,8 ; 1$ AMERICAN LAW OF PROPERTY, supra note $10, \S 1.4$.

12. In the early part of the Middle Ages, land could pass at death only through inheritance, not through a will. Subject to a surviving spouse's dower or curtesy, the land passed through primogeniture to the eldest son of the landowner. 1 AMERICAN LAW OF PROPERTY, supra note 10, § 1.5; Lawrence M. Friedinan, The Law of the Living, the 
had to pay for the privilege. ${ }^{14}$ If he died without heirs, the possession of his land would revert to his lord. ${ }^{15}$

As one might suppose, such a system, which kept the bulk of the kingdom's wealth in the hands of the king and a few powerful lords, was a source of discontent to many of the subjects of the realm. Over hundreds of years, legal changes, only some of which were intentionally reformatory, increased landholders' ability to alienate land freely and mollified this discontent. An early reform came about through the passage of the Statute Quia Emptores. ${ }^{16}$ This law was not passed for the welfare of lowly tenants; rather, it was meant to keep the money from incidents going to the king. The king was losing revenue normally provided by incidents because of the practice of subinfeudation, ${ }^{17}$ the Statute Quia Emptores eliminated this practice by prohibiting the creation of new tenures. With substitution as the only remaining way to make an inter vivos transfer of real property, the incidents owed to a lord survived intact after all property transfers. To pass the new law, however, the lords had to allow land transfer by substitution without a requirement that the tenant first obtain the lord's consent. In addition, tenants no longer had to pay lords (except for the king) fines for these transfers. ${ }^{18}$ The Statute Quia Emptores

Law of the Dead: Property, Succession, and Society, 1966 WIS. L. REv. 340, 360-65.

13. There were two ways to make an inter vivos transfer of land in feudal England. The first involved substitution, whereby one tenant transferred possession of his land to another tenant, leaving all services and incidents due to the lord intact but making them the responsibility of the new tenant. Before the tenant made the transfer, he had to secure his lord's consent, and the substituting tenant had to pledge homage to his new lord. The second method was subinfeudation, a land conveyance through which one tenant conveyed land in such a way that he himself became a mesne lord, taking the transferee as his own tenant. This process, which did not require consent, often denied the conveying tenant's lord the original value of his incidents. For example, if the new mesne lord required of his new tenant only a nommal service such as rent of one peppercorn a year, and the mesne lord died without heirs, the lord remaining would lose the value of the mesne lord's services and receive only the yearly peppercorn rent in services. The incident of escheat, through which the lord would have recovered possession of the land formerly in the mesne lord's possession, would not come into play beyond the peppercorn rent because of the presence of the new tenant. For a fuller explanation of these types of land transfers, see MOYNIHAN, supra note 10, ch. 1, \& 8; 1 AMERICAN LAW OF PROPERTY, supra note $10, \S 1.5$.

14. MOYNIHAN, supra note 10 , ch. $1, \S 7$.

15. Id.

16. 18 Edw. 1, ch. 1 (1290) (Eng.). "Quia Emptores" means "because purchasers." These are the first two words of the statute in Latin. MOYNIHAN, supra note 10, ch. 1, § 8, n.1.

17. See supra note 13 .

18. See Jesse DuKeminier \& James E. Krier, Property 152-53 (2d ed. 1988); 
was thus a milestone in the common law in its promotion of freedom of alienation. This trend toward free alienation continued with the passage of such laws as the Statute of Wills in $1540^{19}$ and the Tenures Abolition Act in $1660{ }^{20}$

The United States also has recognized the concept of freedom of alienation over the past two hundred years. All of the states except Pennsylvamia and South Carolina adopted the Statute Quia Emptores, ${ }^{21}$ and even the U.S. Supreme Court has noted the importance of the freedom to alienate property. ${ }^{22}$ American courts continue to discourage restraints on ahenation today, ${ }^{23}$ although there are a few situations im which a restraint may be valid, e.g., if it is only a partial restramt ${ }^{24}$ or if the restraint is in the form of a covenant in a contract that governs an ongoing relationship between transferor and transferee, namely, when the restraint is part of a lease..$^{25}$

\section{B. The Leasehold Estate}

Throughout their common law existence, leaseholds have had a hybrid legal identity, characterized by their requirement of a contract that dictates the terms of the landlord-tenant relationship.

MOYNiHAN, supra note 10 , ch. $1, \S 8 ; 1$ AMERICAN LAW OF Property, supra note 10 , $\S 1.5$.

19. 32 Hen. 8, ch. 1 (1540) (Eng.) (allowing conveyance of real property through wills, thns eliminating forced primogeniture); see 1 AMERICAN LAW OF PROPERTY, supra note $10, \S 1.5$.

20. 12 Car. 2, ch. 24 (1660) (Eng.) (abolishing, inter alia, fines for alienation of land held of the king); see GRAY, supra note 9, § 4.

21. See 1 AMERICAN LAW OF PROPERTY, supra note $10, \S 1.41$.

22. See, e.g., Beley v. Naphtaly, 169 U.S. 353,363 (1898) (noting "the general rule of law which discourages all restraints upon alienation").

23. See, e.g., United States v. Evans, 844 F.2d 36, 42 (2d Cir. 1988) (contrasting property law with the law governing international arms sales and noting that "[p]roperty law disfavors restraints on ahenation"); Funk v. Funk, 633 P.2d 586, 589 (Idaho 1981) (noting that restraints on alienation are disfavored and, in the case of leases, are construed agamst the lessor); cf. Godley v. Kentucky Resources Corp., 640 F.2d 831, 836 (6th Cir. 1981) ("While restraints on the alienation of property interests are looked on with disfavor, they may nonetheless be upheld when not repugnant to a plain provision of law and not unreasonable.") (enphasis added).

24. A particularly common form of accepted partial restraint is one that restricts the use of the property transferred. See, e.g., Mountain Brow Lodge No. 82 v. Toscano, 64 Cal. Rptr. 816 (Ct. App. 1967) (restricting property to lodge use only).

25. See, e.g., McFadden-Deanville Hotel, Inc. v. Murrell, 182 F.2d 537, 539 (5th Cir. 1950) (acknowledging that assignability is determined by provisions in lease); Julian v. Christopher, 575 A.2d 735, 738 (Md. 1990) ("Contractual restrictions on the alienability of leasehold interests are permitted."). 
As a result, the law has not treated these estates in quite the same way as other real property estates.

In the Middle Ages, when a landowner needed money, he would offer land to a moneylender for a term of years in exchange for a cash consideration. The lender would expect to be able to recover his outlay and more from the use of the land during the tern of the lease. ${ }^{26}$ Such landholdings were classified as nonfreehold estates and were considered by the courts to be personal property instead of real property. ${ }^{27}$ Therefore, if a tenant was dispossessed of his title by someone other than his landlord, his only remedy was money damages. ${ }^{28}$ Eventually, the courts classified these estates as chattels real ${ }^{29}$ because they were personal property in the form of real estate. ${ }^{30}$ In the late fifteenth century, tenants were finally given the right of specific recovery agamst anyone who had wrongfully dispossessed them of their title. ${ }^{31}$

Today, at least some American courts still consider leases to be chattels real. ${ }^{32}$ In addition, because leases also still involve contractual relationships between landlords and tenants, they are subject to both the laws of real property and the laws of con-

26. This system of lending money arose because lenders needed a way around the strict usury laws imposed at the time by the Church. See MoYNIHAN, supra note 10, ch. 3, § 1; A.W.B. SIMPSON, A HISTORY OF THE LAND LAW 71-72 (2d ed. 1986); 1 AMERICAN LAW OF PROPERTY, supra note $10, \S 3.1$.

27. See MOYNIHAN, supra note 10 , ch. $3, \S 1$.

28. See id. A tenant could recover possession against a landlord who wrongfully dispossessed him of his property. See 1 AMERICAN LAW OF PROPERTY, supra note 10, $\S$ 3.1.

29. The definition of "chattel real" is somewhat confusing and not always uniform among the courts. See, e.g., Ex Parte Nottingham, 522 So. 2d 777, 778 (Ala. 1988) (holding that a lease, a chattel real, is personal property for venue purposes); Western Sav. \& Loan Ass'n v. CFS Portales Ethanol I, Ltd., 754 P.2d 520, 521 (N.M. 1988) (classifying a lease as a chattel and therefore not real property). But see Aye v. Fix, 580 P.2d 97, 99 (Mont. 1978) (defining "chattel real" as an interest in real estate and, as such, not personal property). Despite the confusion as to what a chattel real actually is, leases are generally considered to be subject to the dictates of the concept of free alienation, a real property concept. See infra note 33 and accompanying text.

30. See MOYNIHAN, supra note 10 , ch. $3, \S 1$; SIMPSON, supra note 26 , at 76.

31. Through a bit of misconstruction of the action of eiectio firmae, a trespass action for damages, tenants gained the right to specific recovery of their land. This cause of action became popular with landowners as well, who heretofore had been required to Inake more cumbersome claims sounding in real property, and it eventually became known as the inore familiar claim of ejectment. See SiMPSON, supra note 26, at 74-76, 92-93; 1 AMERICAN LAW OF PROPERTY, supra note $10, \S 3.1$.

32. See supra note 29. 
tract. ${ }^{33}$ Thus, there arises a tension between the concept of free alienation of property and the accepted practice of allowing contracting parties to make contractual covenants that may restrict this freedom. ${ }^{34}$ This tension has given rise to the current debate over silent consent clauses, and, predictably, states have divided for the most part along property law and contract law lines. The majority of state courts hold that a silent consent clause should be interpreted strictly for what it says-i.e., when there is no mention of reasonableness in a clause that requires a landlord's consent for subletting or assigning, reasonableness should not be required. ${ }^{35}$ The minority of states, mostly through caselaw, but in a few imstances by statute, read reasonableness into silent consent clauses on the theory that otherwise, the lease imposes an invalid restraint on alienation. ${ }^{36}$

\section{One court noted that}

[t] ]he instrument of lease is thus both an executory contract and a present conveyance, creating between the parties both privity of contract and of estate. Therefore, the obligations which the parties bear to each other may arise out of contract or from the real covenants of the leasehold estate, or sometimes from both.

Arthur Treacher's Fish \& Chips of Fairfax, Inc. v. Chillum Terrace Ltd. Partnership, 327 A.2d 282, 286 (Md. 1974) (citations omitted); see also 1 AMERICAN LAW OF PROPERTY, supra note $10, \S 3.11$.

34. See supra note 25 and accompanying text. There are three categories of direct restraimts: disabling restraints, which make any attempt at alieuation void; forfeiture restraints, which allow for the divestiture of the property from the original transferee at the option of the original transferor if an attempt at alienation by the original transferee is made under specified circumstances; and promissory restraints, which are covenants disallowing alienation to which the parties to a contract have agreed. Consent clauses in leases are promissory restraints in that they are part of a contract; they also may be considered to be forfeiture restraints if as a consequence of an attempt to alienate without consent, the tenant loses possession of the property. See RESTATEMENT (SECOND) OF PROPERTY §§ 3.1-3.3 (1983); id. § 15.2 cmts. b-d (1977); 2 LEWIS M. SIMES, THE LAW OF FUTURE INTERESTS $\S 441$ (1936).

35. See, e.g., Slavin v. Rent Control Bd., 548 N.E.2d 1226, 1229 (Mass. 1990) (rent control residential lease); Gruman v. Investors Diversified Servs., Inc., 78 N.W.2d 377, 381 (Mim. 1956) (commercial lease); Segre v. Ring, 170 A.2d 265, 266 (N.H. 1961) (resort town residential lease); F \& L Ctr. Co. v. Cunninghaun Drug Stores, Inc., 482 N.E.2d 1296, 1300 (Ohio Ct. App. 1984) (commercial lease); Abrahamson v. Brett, 21 P.2d 229, 232 (Or. 1933) (residential lease); B \& R Oil Co. v. Ray's Mobile Homes, Inc., 422 A.2d 1267, 1267 (Vt. 1980) (commercial lease).

36. See, e.g., ALASKA STAT. \& 34.03 .060 (1990) (residential lease); DEL. CODE ANN. tit. 25, § 5512(b) (1989) (residential and commercial leases); HAW. REV. STAT. § 516-63 (1988) (lease assignments); N.Y. REAL PROP. LAW § 226-b (McKinney 1989) (residential lease); Homa-Goff Interiors, Inc. v. Cowden, 350 So. 2d 1035, 1038 (Ala. 1977) (commercial lease); Kendall v. Ernest Pestana, Inc., 709 P.2d 837, 849 (Cal. 1985) (en banc) (saine); Jack Frost Sales, Inc. v. Harris Trust and Sav. Bank, 433 N.E.2d 941, 949 (Ill. App. Ct. 1982) (same); Julian v. Christopher, 575 A.2d 735, 738 (Md. 1990) (same); 


\section{A. Dispensing with the Due-on-Sale Clause Analogy}

Although contract and property law concepts relevant to leases are reconcilable, this arduous process would not be necessary in the silent consent clause context if courts could simply look to the law of due-on-sale clauses to resolve the debate. Unfortunately, due-on-sale clauses and silent consent clauses are alike ouly in that they both have an effect on real property transfers through a contract clause, one in a mortgage and the other in a lease. If one looks beyond this superficial similarity, it is apparent that the former is not a restraint on alienation, whereas the latter is, and that the former is clear as to its operation, whereas the latter is not. Therefore, the law should not treat the two clauses in the same inaimer.

Prior to the passage of the Garn-St. Germain Depository Institutions Act $^{37}$ some courts argued that due-on-sale clauses should be enforced only if reasonable, saying that such clauses hindered the ability to sell and thus were restraints on alienation that should be enforced sparingly. These courts reasoned that a due-on-sale clause and its accompanying threat of higher interest rates on the prospective buyer's loan either would inhibit the seller's chance of actually finding a buyer or would force the seller to lower the selling price to compensate for the higher rates of interest the buyer would have to pay. ${ }^{38}$ Other courts argued correctly that a due-on-sale clause does not itself hinder the sale of property in any way but only describes a financial consequence of transfer. If the seller has difficulty selling because interest rates are rising, the problem with selling is due to the econormic condi-

Kruger v. Page Management Co., 432 N.Y.S.2d 295, 308 (Sup. Ct. 1980) (residential sublease, interpreting New York statute).

Some of these minority courts also cite the contract law requirement of good faith and fair dealing in support of the requirement of reasonableness. Such arguments are a nascent form of reconciliation of the relevant property and contract law concepts, but apparently they have not been as complete or as convincing as they need to be to win the support of the majority of states. See, e.g., Kendall, 709 P.2d at 844-45; Julian, 575 A.2d at $738-39$.

37. See supra note 2 and accompanying text.

38. See, e.g., Wellenkamp v. Bank of Am., 582 P.2d 970, 974-75 (Cal. 1978) (en banc); Sonny Arnold, Inc. v. Sentry Sav. Ass'n, 633 S.W.2d 811, 816-18 (Tex. 1982) (Spears, J., concurring). 
tions of the time, not to the due-on-sale clause in the seller's mortgage agreement. ${ }^{39}$ Due-on-sale clauses thus are not restraints on alienation.

Silent consent clauses, on the other hand, can dictate whether a tenant can make a sublease or assignment at all. If the landlord refuses to consent to a sublease or assignment, the tenant's holding is rendered completely makienable. The consent clause thus serves as a direct restraint on ahenation. ${ }^{40}$

Also, in contrast to silent consent clauses, due-on-sale clauses are clear on their face as to their operation: if a transfer of property is made, the lender may imvoke the clause. ${ }^{41}$ Silent consent clauses are not quite so clear. They state that if a transfer is made without consent, the landlord may invoke the clause. ${ }^{42}$ The unembellished "without consent" phrase leaves the tenant uncertain as to when consent may be withheld and thus as to whether the clause will be invoked. When consent clauses dictate that consent cannot be withheld unreasonably, the tenant knows where he stands. Unfortunately, silent consent clauses contain no such language. Simce each state varies in its treatment of such clauses, tenants cannot always know whether reasonableness will be read into the clause. ${ }^{43}$

39. See Williams v. First Fed. Sav. \& Loan Ass'n, 651 F.2d 910, 926 (4th Cir. 1981); Wellenkamp, 582 P.2d at 977-79 (Clark, J., dissenting); Medevoi v. American Sav. and Loan Ass'n, 152 Cal. Rptr. 572, 583 n.1 (Ct. App. 1979); Occidental Sav. and Loan Ass'n v. Venco Partnership, 293 N.W.2d 843, 848 (Neb. 1980); see also Richard C. Maxwell, The Due-on-Sale Clause: Restraints on Alienation and Adhesion Theory in Califormia, 28 UCLA L. REV. 197, 200 (1980).

This point is made clearer by the observation that a buyer of completely unencumbered property also is faced with the prospect of paying current interest rates if a mortgage note is agreed to at the time of purchase.

40. See supra note 34.

41. Due-on-sale clauses typically take the form of the clause that was at issue in Wellenkamp, which stated that if the trustor "sells, conveys, alienates ... said property ... or becomes divested of [his] title or any interest therein ... in any manner or way, ... Beneficiary shall have the right at its option, to declare said note . . . secured hereby . . . immediately due and payable without notice." Wellenkamp, 582 P.2d at 972.

42. Silent consent clauses tend to be brief and of the following general form: a lessee may not "assign this lease nor underlet said premises, or any part thereof, without the consent of Lessor in writing." Gruman v, Investors Diversified Servs., Inc., 78 N.W.2d 377, 378 (Minn. 1956).

43. Not only are there inconsistencies among the states, see supra notes 35-36 and accompanying text, but there also may be imconsistency within a particular jurisdiction. See infra Part IV. 
Because of these fundamental differences between the two types of clauses, the analyses of due-on-sale clauses made by the courts and Congress are not particularly helpful in the determination of how consent clauses in leases should be treated. The second approach to the silent consent clause problem, the reconciliation of seemingly competing contract and property law concepts, is accordingly necessary.

\section{B. Justifications for the Invocation of Reasonableness Based on Real Property Law Policy}

During the Middle Ages, landholders justified the need for free ahenation of land by pointing out that without laws promoting ahenation, the king and his powerful lords would control most of the land in England and the wealth that came with it. ${ }^{44} \mathrm{Al}$ though the United States is not subject to such a repressive feudal scheme, numerous public pohicies contimue to support tenants' views that property should be freely alienable.

Society is affected in several ways when property is rendered inalienable. Tenants are obviously affected. If a tenant is unable to alienate because of the denial of consent to sublet or assign, immobility is a probable consequence. This result occurs whether the lease is residential or commercial. If, for example, a person lias the opportunity to take a new job but must move to do so, prohibition against subletting or assigning his residence limits his options. Of course, the tenant can always break his lease, but then he will suffer the consequences inherent in such action, such as having to continue to pay rent for the remainder of his lease term. ${ }^{45}$ For many people, the requirement of paying two rents for

44. See supra Section I(A).

45. Some leases are admittedly lenient with regard to residential tenants who need to move because of an employer's decision. Such leases contain clauses allowing for monthto-month rental after some initial rental period; in these cases, only 30 days' notice is needed to cancel a lease. Other leases contain clauses, such as the following, regarding moves for employment reasous: "You may terminate this Lease after the first 180 days of the term if your present employer transfers You outside a fifty (50) mile radius from the Community provided You [give 30 days' notice, proof of transfer, leave the premises in good condition, pay all sums due, and comply with the other terms of the lease]."

Although lenient in certain circumstances, however, these clauses do not help the person who is changing from one job to another, who is starting a new job, or who has not occupied his apartment for the requisite amount of time. In such situations, the tenant breaking the lease may be required by even the most generous leases to pay several months' rent, surrender the security deposit, and pay costs incurred in attempting to re- 
several months is a burden not easily overcome and may prevent any move at all, thereby harming both the tenant and his potential employer and profession. In the commercial setting, the scenario is similar, although consequences may vary among commercial tenants depending on their size and stability. Arguably, the most likely to be hurt are sinall businesses that need to move to take advantage of a larger space or a more desirable location. Especially in the case of a small business lacking excess capital, the law would seem terribly harsh if it encouraged the use of lease clauses that kept such an entity from improving its financial position through an otherwise feasible relocation. In either residential or commercial lease situations, the tenant who is restricted from subletting or assigning and who is unable to afford the consequences of breaking a lease will be restrained froin increasing his wealth, enlarging his business, or otherwise improving his lifestyle.

Beyond the concerns of tenants theinselves are those of the community as a whole. From an altruistic viewpoint, the community should be concerned when the human potential of a tenant is wasted to some extent because he cannot improve his lot in life due to lease restrictions. From a more selfish viewpoint, one would expect the community to want its tenants to be in the best financial condition possible; the more money tenants have to spend, the better off financially the community will be. A tenant who, due to a slow rental market, cannot afford the costs associated with breaking his lease not only misses the opportunity to improve his personal financial situation but also is unable to use the imcreased buying power that might have come with his move.

rent the apartment. A typical clause may read as follows:

If for any reason other than those set forth . . . above [relating to moves required by an employer] You desire to terminate this Lease agreement prior to the designated ending date, You shall give Us thirty $(30)$ days written notice and You will be charged a set termination fee equivalent to two (2) month's [sic] rent as stated on your current Lease agreement. In addition, Your deposit will be held to cover all costs involved in preparing the apartment for a new tenant, as well as those costs We incur attempting to re-rent Your apartment.

See Restatement (SECOND) OF PROPERTY \& 13.1 (1977).

A landlord also may be mjured if a tenant cannot alienate. If the lease calls for forfeiture on improper alienation, the landlord is without an occupant; if the tenant surrenders the lease, the landlord may be required by law to mitigate damages. See, e.g., WIs. STAT. ANN. \& 704.29 (West 1981); McGuire v. City of Jersey City, 593 A.2d 309, 314 (N.J. 1991) (applying the requirement of mitigation to commercial, as well as residential, lessors); Reid v. Mutual of Omaha Ins. Co., 776 P.2d 896, 906 (Utah 1989) (requiring landlord to take "commercially reasonable" steps to mitigate damages). 
Similarly, in a strong rental market, a tenant who is restrained from subletting and thereby prevented from taking advantage of increasing rental rates is unable to consume the proceeds froin the sublease. ${ }^{46}$ Even if, under the restraints imposed by a consent clause denial, the tenant can meet the financial burdens that accompany breaking a lease, ${ }^{47}$ the landlord then must find a new tenant, and until a new tenant is found, the property will lie einpty. The empty rental property could then be a target for vandalism and, in any event, would not have a resident to keep it froln falling into disrepair. ${ }^{48}$

Restraints also discourage improvement of property. Admittedly, in the case of a residential lease, a landlord may have good reason not to allow changes to the property because the space is already adapted to residential living. ${ }^{49}$ In commercial settings, however, especially when changes are minimally destructive or modernize the property, a landlord nnay allow the tenant to change decor, add machinery, or cliange the property in some other way to make it more useful than when it was first rented. ${ }^{50}$ If the tenant knows that he may then sublet or assign if necessary or advantageous, lie is more likely to make improvements that will aid the completion of such a transfer. If, however, the tenant believes that he will not be able to benefit financially from any improvements he makes, he will have little incentive to make more than the bare minimum of improvements needed to run his business. ${ }^{51}$ The law should encourage the making of such improveinents because property that has been improved to ineet the

46. See 6 AMERICAN LAW OF PROPERTY, supra note 10, \& 26.3.

47. See supra note 45 .

48. When the property is likely to stand idle for a substantial length of time, the landlord could probably save himself some trouble if he allowed the tenant to sublet or assign because then he would not have to search for a new tenant himself.

49. The following is a typical provision under which a landlord could refuse to allow changes: "[T]he LESSEE[,] for himself and his assigns, hereby COVENANTS with the lessor ... that he and his executors, administrators, and assigns ... will not, without the consent in writing of the lessor, ... make or suffer any alterations or additions in or to the [premises]." URIEL H. CROCKER, NOTES ON COMMON FORMS 271-72 (Guy Newhall ed., 5th ed. 1913); see also ALVIN L. ARNOLD ET AL., MODERN REAL EsTATE AND MORTGAGE FORMS, Form 90.2, at II-197 (3d ed. 1986).

50. A commercial lease might read as follows: "Tenant will not paint the Premises or make or permit anyone to make any alterations in or additions thereto ... without the prior written consent of Landlord." ARNOLD ET AL., supra note 49, Form 45.1, at II-19.

51. See 6 AMERICAN LAW OF PROPERTY, supta note 10, \& 26.3. 
demands of new technologies or changing consumer tastes is likely to be used more efficiently and contmually than property that is allowed to become out-of-date or unattractive.

Although the foregoing arguments support tenants' views that leased property should be freely alienable, there are two sides to the story; tenants would obviously prefer unrestricted free alienability, but landlords also have rights. Thus, one could argue that landlords should have the right to refuse consent for any (or no) reason; because leases are by definition not of indefinite duration, any restraint on alienation is only temporary. ${ }^{52}$ This position is untenable for several reasons. First, any prospective tenant who is trying to move into a particular property by way of a sublease or assignment is not likely to wait for the end of a lease term to do so. Therefore, the issues of mobility and idleness are still at hand. Second, many lease terms are not all that short, ${ }^{53}$ so "temporary" takes on a relative meaning. With respect to the age of the universe, a ten-year lease covers a short span of time, but with respect to a person's lifetime or a business cycle, ten years may seein closer to an etermity.

There are, however, several public policies that support a landlord's right to refuse consent to a proposed sublease or assignment if sucli consent is withlield reasonably. One such arguinent is that two parties should be allowed to make a contract limiting their riglits as they so choose. ${ }^{54} \mathrm{~A}$ second argument espoused by

52. See, e.g., Carma Developers (Cal.), Inc. v. Marathon Dev. Cal., Inc., 826 P.2d 710, 719 (Cal. 1992) (noting that lease restraints, by definition, are limited by the duration of the lease).

One also could argue that a landlord has the right to refuse consent to alienate for purely discriminatory reasons because landlords are not state actors and are thus not subject to constitutional claims under the Fourteenth Amendment. Given the many civil rights laws prohibiting discrimination, however, especially in the area of housing, the idea that public policy would support outright discrimination in leasing situations is laughable. Public policy does not support the right to discriminate; the laws simply do not prohibit discrimination in every private situation imaginable. See, e.g., The Fair Housing Act 42 U.S.C. $\S 3604$ (1988) (prohibiting discrimination in the sale or rental of loousing based on race, color, religion, sex, familial status, or national origin); The Civil Rights Act of 1866 id. § 1982 (prohibiting racial discrimination in the housing context). But see id. \& 3603(b) (exempting from the prohibitions of the Fair Housing Act owners who rent in certain residential situations). Individual states also may have more protective laws.

53. Commercial leases often run for five or ten years, see, e.g., Jolınson v. Jaquith, 189 So. 2d 827 (Fla. Dist. Ct. App. 1966) (five years); Dress Shirt Sales, Inc. v. Hotel Martinique Assocs., 190 N.E.2d 10 (N.Y. 1963) (ten years), but may be for mucl longer terms, see, e.g., Trustees of the First Presbyterian Church v. Oliver-Tyrone Corp., 375 A.2d 193 (Pa. Super. Ct. 1977) (999 years).

54. See Drake v. Eggleston, 108 N.E.2d 67, 69 (Ind. Ct. App. 1952) (noting that 
lessors has to do with a landlord's ability to protect his investment. As many courts and commentators have pointed out, a landlord has theoretically chosen his tenant with care and should not be forced to accept an unsuitable tenant should the original tenant choose to sublet or assign to such a person or entity. ${ }^{55}$ On the other hand, as discussed above, a tenant should not be denied the ability to alienate. A compromise position that allows a tenant and his landlord to discuss and agree on the new tenant would seem to be the best option. ${ }^{56}$ In this way, both parties' rights with respect to alienation are honored.

\section{Justifications for the Invocation of Reasonableness Based on the Rules of Contract Interpretation}

In addition to the right of a landlord to protect his property investment, there also exists the freedom to contract. As a matter of practice, courts allow landlords and tenants to bargain for restrictions on alienation of the subject property. ${ }^{57}$ One might beheve, then, that the majority of states, which hold that a landlord's refusal to give consent to sublet or assign may be arbitrary and capricious, ${ }^{58}$ are correct. This behief that the silent consent clause gives all power to the landlord is flawed, however, because the rules of contract interpretation dictate that more than the wording of one clause should be examined when determining the meaming

although courts do not look favorably on restraints on alienation, covenants may be used to restrict subletting); Kruger v. Page Management Co., 432 N.Y.S.2d 295, 300 (Sup. Ct. 1980) (noting that a lease is a contract and that the parties to it are free to agree to anything they want, absent violation of law or public policy). For a discussion of this contract argument, see infra Section $\Pi(C)$.

55. See, e.g., Kendall v. Ernest Pestana, Inc., 709 P.2d 837, 844 (Cal. 1985) (en banc) (citing authorities that allow a landlord to protect his investment); Jack Frost Sales v. Harris Trust \& Sav. Bank, 433 N.E.2d 941, 949 (IIl. App. Ct. 1982) (requiring the tender of a suitable sublessee as a condition precedent to the lessor's duty to consent to the sublease); SIMES, supra note $34, \S 470$.

56. This compromise position advocating reasonableness, although adopted by only a minority of states, has been adopted by the Restatement of Property and in England. See RESTATEMENT (SECOND) OF PROPERTY (DONATIVE TRANSFERS) §§ 4.1(2), 4.2(3) (1983); RESTATEMENT (SECOND) OF PROPERTY (LANDLORD AND TENANT) \& 15.2 (1977); Landlord and Tenant Act, 1927, $17 \& 18$ Geo. 5, ch. 36, \& 19(1) (Eng.).

57. See, e.g., McFadden-Deauville Hotel, Inc. v. Murrell, 182 F.2d 537, 539 (5th Cir. 1950); Drake, 108 N.E.2d at 69; Julian v. Christopher, 575 A.2d 735, 738 (Md. 1990); Kruger, 432 N.Y.S.2d at 300.

58. See, e.g., Kendall, 709 P.2d at 841; Gruman v. Investors Diversified Servs., Inc., 78 N.W.2d 377, 379 (Minn. 1956). 
of an ambiguous contract term, especially when it is clear that the parties to the lease have not engaged in any actual "bargaining." Because silent consent clauses fall into this category of ambiguous contract clauses, ${ }^{59}$ these rules of interpretation should be examined carefully when determining whether a silent consent clause should incorporate the idea of reasonableness even when that concept is unstated. ${ }^{60}$

The essence of contract interpretation hes in determining what each party has bargained for or, in other words, what the intent of each party was at the time the contract was made. ${ }^{61}$ With regard to the interpretation of a lease's silent consent clause, courts should examine the language of the clause, the issue of reliance, the relative bargaining power of the parties, and the parties' good faith.

With respect to a silent consent clause standing alone, the wording $^{62}$ is unclear on its face. ${ }^{63}$ There may be other language, however, that a court could examine to clarify the clause. If a contract contains explanatory terms providing that consent may not be withheld unreasonably or, conversely, that consent may be withheld for any reason, then there is no interpretive problein

59. The majority of courts interpret a silent consent clause to mean that the landlord may withhold consent without giving any reason whatsoever. On the other hand, a clause that merely states a need for consent of a landlord hardly qualifies as a "clear and unambiguous" statement, Gruman, 78 N.W.2d at 381, of both parties' intentions that the landlord may prevent alienation for a reason as arbitrary as that he is in a bad mood on any given day. It is thus also feasible that one might imterpret a silent consent clause to mean that any landlord withholding consent must have a valid reason for doing so. As a Massachusetts court noted over fifty years ago, "It would seem to be the better law that when a lease restricts a lessee's rights by requiring consent before these rights can be exercised, it must have been in the contemplation of the parties that the lessor be required to give some reason for withholding consent." Granite Trust Bldg. Corp. v. Great Atl. \& Pac. Tea Co., 36 F. Supp. 77, 78 (D. Mass. 1940); see also Julian, 575 A.2d at 738 ("If a landlord is allowed to arbitrarily refuse consent to an assignment or sublease, for what in effect is no reason at all, that would virtually nullify any right to assign or sublease.").

60. The fact that a lease is a real estate contract does not take it out of the realm of traditional contract interpretation. See, e.g., Javins v. First Nat'l Realty Corp., 428 F.2d 1071, 1075 (D.C. Cir.) (concluding that "leases of urban dwelling units should be interpreted and construed like any other contract"), cert. denied, 400 U.S. 925 (1970).

61. A contract is "a promise or set of promises," RESTATEMENT (SECOND) OF CONTRACTS $\S 1$ (1981), and "a promise is a manifestation of intention to act or refram from acting in a specified way." Id. $\S 2$.

62. For the language of a typical silent consent clause, see supra note 42 .

63. See supra note 59 . 
with the consent clause. In these cases, however, the consent clause could hardly be said to be "silent." 64

Because the language of a truly "silent" consent clause is not necessarily indicative of the true intent of both landlord and tenant, other interpretive devices should be used to uncover this intent. One such device is the analysis of any rehance by either the landlord or the tenant. One could argue that a landlord who rehied on the "without consent" language of a silent consent clause was justified in thinking that all control of alienation was in his hands. This conclusion would imply, however, that the landlord actually believed a tenant would agree to such a construction of this term. Courts that allow the withholding of consent for absolutely no reason when a silent consent clause is involved ${ }^{65}$ walk among the willfully blind, ignoring the reality that "[in]ost tenants probably would not understand that a clause stating 'this lease may not be assigued or sublet without the landlord's written consent' means the same as a clause stating 'the tenant shall liave no right to assign or sublease." $" 166$

A tenant's rehance on freedom of alienation is more justified. In the case of the unsophisticated residential tenant, it seems fair to say that many people are aware of someone who has sublet his college apartment for the summer or assigned the remainder of his lease after graduation and believe that they can do the same. On a more esoteric level, lawyers for both sides who negotiate more complicated commercial leases should have some knowledge of the long history of property law innovations supporting free alienation, not to mention awareness of modern caselaw and statutory law, which provide for free alienation unless it is otherwise expressly forbidden. ${ }^{67}$ Therefore, the tenant's expectation of at least a mo-

64. When the lease truly is silent and does not clarify when a landlord may withhold consent, the only other language to which a court might look for guidance wonld be parol evidence. If a court does have access to relevant parol evidence, this evidence may well resolve any questions of intent concerning the consent clause. Since cases in which intent is clear are not the subject of this Note, however, situations in which admissible parol evidence is available are not considered.

65. See, e.g., Dress Shirt Sales, Inc. v. Hotel Martinique Assocs., 190 N.E.2d 10, 11 (N.Y. 1963) (holding that in New York, it is settled law that unless a lease consent clause expressly requires reasonableness, arbitrary refusal of consent is permissible).

66. Julian v. Christopher, 575 A.2d 735, 738 (Md. 1990).

67. See, e.g., DEL. CODE ANN. tit. 25, § 5512(a) (1989) (stating that unless otherwise agreed, a tenant may sublet or assign); Julian, 575 A.2d at 738 (citing ROBERT S. SCHOSHINSKI, AMERICAN LAW OF LANDLORD AND TENANT $§ 5.6$ (1980) and 1 AMERI- 
dicum of freedom to sublet or assign is much more justified than a landlord's rehance on the notion that he may withhold consent for no reason at all.

The issue of the relative bargaining power of the parties is closely related to the reliance issue in that it also has to do with each party's level of sophistication. When both parties are equally sophisticated or represented by counsel, as is often the case when a long-term commercial lease is being negotiated, the bargaining power of each party may not be an issue. When the tenant is less sophisticated than the landlord, ${ }^{68}$ lowever, as is true in soine commercial and inany residential leasing situations, courts should make a determination of the effect the tenant's position may have on his beliefs about the lease and his intentions at the time the lease was signed. The tenant who is unsophisticated is not likely to think to ask about an alienation clause that appears to require only that the tenant ask permission before subletting or assigning. Further, since a residential lease contract could arguably be considered to be a contract of adhesion, ${ }^{69}$ a tenant might not even understand the language used in the consent clause. ${ }^{70}$ Recognizing that the boiler-plate language used in such contracts is hard for a non-lawyer to understand, courts have traditionally construed clauses in adhesion contracts in favor of the less sophisticated party. ${ }^{71}$ Even if a court does not consider the lease tantamount to an adhesion contract, it is still common practice to construe ambiguous language against the party in whose favor the benefit of the clause accrues. ${ }^{72}$ When there is a silent consent clause dispute

CAN LAW OF PROPERTY, supra note 10, § 3.56); Kruger v. Page Management Co., 432 N.Y.S.2d 295, 299 (Sup. Ct. 1980) (holding that under the common law of New York, a tenant may alienate at will if there is no express restriction in either contract or statute).

68. Obviously, there could theoretically be occasions when the landlord is less sophisticated than the tenant. The court would need to take this switching of roles into account if it arose.

69. As Professor Maxwell has noted, "adhesion contract" has been defined as "a standardized contract prepared entirely by one party to the transaction ... under such conditions that the 'adherer' cannot obtain the desired product or service save by acquiescing in the form agreement." Maxwell, supra note 39, at 209 (quoting Steven v. Fidelity \& Casualty Co., 377 P.2d 284, 297 (Cal. 1962)).

70. Although inost people probably understand the concept of subletting, it is not unimaginable that they would not understand the words "underletting" or "assigning."

71. See, e.g., Steven, 377 P.2d at 294-98 (approving construction in favor of less sophisticated party in cases involving adhesion contracts).

72. This practice holds true regarding all types of contracts, not just leases. See, e.g., Granite Trust Bldg. Corp. v. Great Atl. \& Pac. Tea Co., 36 F. Supp. 77, 78 (D. Mass. 
between a landlord and his less sophisticated tenant, then, the clause should be construed in favor of the tenant, i.e., in favor of preventing the unreasonable withholding of consent.

One final argument based on contract interpretation theory that supports the reading of reasonableness into silent consent clauses is the concept of "good faith and fair dealing."73 Several courts, borrowing a standard from the Uniform Commercial Code, have advanced the idea that the good-faith doctrine requires that a standard of "commercial reasonableness" be read into silent consent clauses. ${ }^{74}$ Even if one does not agree that standards adopted for use in governing the sale of goods apply to leasing transactions, the doctrine as it is set forth in the Restatement of Contracts is still relevant to the silent consent clause issue: if a landlord knows that a tenant is not likely to understand the implications of the landlord's interpretation of a silent consent clause, he could hardly be considered to be acting in good faith if he fails to explain tlie clause until after the tenant announces plans to sublet or assign.

Once a court has determined that a consent clause stands alone and unclarified in a given lease contract, analysis of the lease through the use of standard contract interpretation methods will point to favoring the tenant over the landlord in consent clause disputes. In these situations, contract law, like the policies favoring free alienation of property, supports the reading of a requirement of reasonableness into silent consent clauses.

1940) (holding that a covenant calling for consent of landlord prior to assignment by tenant is for the landlord's benefit and should be construed in favor of tenant); Great Am. Mut. Indemn. Co. v. Jones, 144 N.E. 596, 596 (Ohio 1924) (holdmg that insurance policies should be construed like any other contract and that poicies subject to more than one interpretation should be construed in favor of the insured) (quoting Mumaw v. Western \& S. Life Ins. Co., 119 N.E. 132, 132 (Ohio 1917)); VNB Mortgage Corp. v. Lone Star Indus., Inc., 209 S.E.2d 909, 913 (Va. 1974) (holding that with respect to a mechanic's hen, anbiguous contract provisions should be construed against the party for whose benefit the clauses were inserted).

73. This concept is embodied in the Restatement of Contracts: "Every contract imposes upon each party a duty of good faith and fair dealing in its performance and its enforcement." RESTATEMENT (SECOND) OF CONTRACTS $\& 205$ (1981).

74. See Kendall v. Ernest Pestana, Inc., 709 P.2d 837, $844-45$ (Cal. 1985) (en banc); see also U.C.C. \& 1-203 (1991) (imposing duty of good faith and fair dealing); id. \& 2-103(b) (defining good faith under Article 2 as "honesty in fact and the observance of reasonable commercial standards"). 


\section{DEFINING "REASONABLE"}

Having determined that the policies supporting free alienation of property and the rules governing contract interpretation both require that reasonableness be read into silent consent clauses, there remains the task of defining what is included in the concept of reasonableness. Courts that require reasonableness often clarify the term, but they usually do so only with respect to a proposed replaceinent tenant. ${ }^{75}$ Seldom discussed, but just as important, is the consideration of whether it is reasonable for a landlord to withhold consent when a tenant wants to ahenate so that the tenant can take advantage of rising rental rates. ${ }^{76}$ By balancing the justification for the restraint against the policies that support free ahenation, this Part sets out general guidelines concerning what are reasonable justifications for a landlord's withholding of consent.

The first part of the balancing test concerns arguments supporting the restraint. As discussed above, ${ }^{n}$ there are really only two such arguinents that survive scrutiny. One, the argument that as a contract, a lease should be taken at face value when its terms are clear, is valid only when the clause is not actually "silent" but instead is accompanied by clarifying terms within the contract. ${ }^{78}$ When this clarifying language is present, any withholding of consent that does not otherwise violate the law ${ }^{79}$ is inherently rea-

75. See, e.g., Johnson v. Jaquith, 189 So. $2 d 827,829$ (Fla. Dist. Ct. App. 1966) (declaring plaintiff's withholding of consent reasonable because, inter alia, it was based on the financial status of defendant); Jack Frost Sales v. Harris Trust \& Sav. Bank, 433 N.E.2d 941, 949 (Ill. App. Ct. 1982) (stating that it is reasonable to withhold consent if proposed replacement is not "ready, willing and able" to take over for alienating tenant); Julian v. Christopher, 575 A.2d 735, 739 (Md. 1990) (giving examples of reasonable instances of withholding consent, such as when the prospective tenant is financially irresponsible or wants the property for a use for which it is not intended); $c f$. Kendall, 709 P.2d at 845 (considering also the reasonableness of a refusal of consent based on the landlord's desire to charge a higher rent than provided for in the original lease).

76. It may be suggested that a tenant who alienates to take advantage of rental rates higher than those called for in his lease will have to rent another space at current rates and thus lose any extra money he might make on his sublease or assignment. This argument fails to consider situations such as a residential tenant who wants to move to a smaller place or a commercial tenant who is relocating to a more affordable area or who is going out of business and who needs a lot of cash. See Carma Developers (Cal.), Inc. v. Marathon Dev. Cal, Inc., 826 P.2d 710, 719 \& n.5 (Cal. 1992).

77. See supra Part II.

78. See supra notes $62-64$ and accompanying text.

79. This Note assumes that acting in a matter that is illegal is per se unreasonable. An example of illegal refusal of cousent would be refusal based purely on the race of 
sonable because the intentions of the parties to restrain alienation are clear. ${ }^{80}$ When the consent clause is truly silent, the other justification for withholding consent comes into play, namely, that the landlord should be able to protect his investment. ${ }^{81}$ The ultimate questions when determining whether a refusal of consent pursuant to a silent consent clause is reasonable, then, are whether the landlord really is acting to protect his investment and, if so, whetlier the importance of doing so outweighs the policies supporting free alienation.

There are four types of situations in which a landlord might, and often does, withhold consent using this justification. First, the landlord may give no other reason whatsoever, arguing that he has the right to be arbitrary or capricious because of the presence of the consent clause. ${ }^{82}$ With no evidence of threatened harm from the transfer, the rationale of a need to protect one's investment is baseless and simply unacceptable. ${ }^{83}$

Second, a landlord may try to justify his actions by claiming that there is a problem with a characteristic of the proposed substitute tenant. ${ }^{84}$ In these cases, the withholding of consent on the basis of the landlord's desire to protect his imvestment may be reasonable, depending on whether consent is withheld because of a characteristic, such as race or rehgion, that would have no direct effect on the person's or entity's ability to be a model tenant, or whether it is withheld because of a characteristic, such as history of financial irresponsibility, that by its nature could directly affect the person's or entity's ability to conform to the covenants in the lease. As one court stated, when evaluating a prospective tenant, a landlord must do so "using the same standards apphed in the

the proposed sublessee or assignee. See supra note 52 .

80. This principle holds unless duress or misrepresentation at the time of signing can be shown. Such hazards are a possibility in any contract situation, however, and present no additional problems with respect to lease contracts as coinpared to any other type of contract.

81. See supra notes 55-56 and accoinpanying text.

82. See, e.g., Dress Shirt Sales, Inc. v. Hotel Martinique Assocs., 190 N.E.2d 10, 11 (N.Y. 1963).

83. See supra note 59; see also Funk v. Funk, 633 P.2d 586, 589 (Idaho 1981) ("However, no desirable public policy is served by uploolding a landlord's arbitrary refusal of consent merely because of whim or caprice ....").

84. See, e.g., Johnson v. Jaquith, 189 So. 2d 827, 829 (Fla. Dist. Ct. App. 1966); Jack Frost Sales v. Harris Trust \& Sav. Bank, 433 N.E.2d 941, 949 (Ill. App. Ct. 1982); Julian v. Christopher, 575 A.2d 735, 739 (Md. 1990). 
acceptance of the original lessee." ${ }^{285}$ Any time consent is withheld in contravention of civil rights laws, then, the landlord's action is per se unreasonable. It is more difficult to assess the question of reasonableness when the discrimination is not necessarily illegal. ${ }^{86}$ In the balance, however, the right to discriminate, already legally prohibited in many settings and thus on shaky pohicy ground anyway, does not outweigh the policies supporting free alienation, particularly the need for freedom of movement. ${ }^{87}$ On the other hand, if the basis for withholding consent is a claracteristic that would affect a prospective tenant's ability to perform lis duties as required by the lease, the landlord nay be justified in refusing to consent. Faced with a prospective tenant who, for example, has a history of financial problems or who has been thrown out of apartments in the past for excessive noise, a landlord is reasonable if he worries that such a tenant will harm his imvestment. A tenant who wishes to sublet or assign could hardly make a case that his rights are being violated or that the landlord is being unreasonable by withholding consent when the proposed new tenant is obviously unsuitable and could do harm to the landlord financially or with respect to his reputation for providing habitable and safe living units or commercial space.

The third situation in which a landlord may decide to withliold consent is when lie questions the use to which the proposed substitute tenant is planning to put the premises. A tenant who wishes to sublet or assign must present a suitable new tenant, and if the new tenant wants to use the property in a way that violates zoning laws, will pollute the surrounding area, or for which the property is not equipped, even if there is no lease term explicitly forbidding such use, the landlord is justified in withholding consent. The threat to the imvestment is greater than the policies supporting the tenant's freedom to alienate; the tenant is limited only in that he must take a modicuin of care when finding a sublessee or assignee.

85. Shaker Bldg. Co. v. Federal Lime \& Stone Co., 277 N.E.2d 584, 587 (Shaker Heights, Ohio Mun. Ct. 1971), rev'd, 1972 WL 20379 (Ohio Ct. App. Mar. 2, 1972), as noted in F \& L Ctr. Co. v. Cunningham Drug Stores, Inc., 482 N.E.2d 1296, 1299 (Ohio Ct. App. 1984). Although this case was overruled, its reasoning is still sound. See infra note 91 and accompanying text.

86. See supra note 52 .

87. See supra text accompanying note 45 ; see also Griffm v. Breckenridge, 403 U.S. 88, 105-06 (1971) (recognizing the constitutional right of interstate travel). 
Finally, a landlord might try to withhold consent to take advantage of a inarket in which rental rates are rising-i.e., the landlord might refuse consent so that the tenant will forfeit the lease and the landlord can then re-let the unit himself. In this way, the landlord would receive the increase in rent instead of the original tenant. Assuming a suitable substitute tenant has been put forth, it is not reasonable for a landlord to withhold consent in these situations under the guise of protecting his investment. If the prospective tenant is suitable, the landlord's investment is not in danger froin the sublease or assignment. Instead of acting to protect his investment, the landlord who withholds consent and then declares an alienated lease broken is trying to get more than his bargained-for rent. ${ }^{88}$ By agreeing to a lease for a certain time period, a landlord has invested in such a way that he hopes he has inade a good deal regarding the amount of inoney he has put into his investment coinpared to how inuch he will get in rent. If the landlord has made a poor calculation, that is too bad. After all, if market rates go down, adversely affecting the tenant's ability to sublet for a higher rate than is in his lease, the tenant's only recourse is to renegotiate the lease, an action the landlord will probably refuse to take. The landlord has similarly bargained and has promised the tenant the use of the premises as he sees fit for the length of the lease term, as long as the tenant acts within the law. In so doing, the landlord has bargained away any right to take advantage of increased rental rates unless he adds specific terms to the lease allowing for rent increases over time or rent rate re-evaluation on a periodic basis. In a residential situation the landlord who withholds consent seems especially unjustified because typically the landlord would not allow the original tenant to bargain for the initial rent. Unlike the situation in which the tenant must provide a substitute tenant who is equally as suitable as the original tenant and the terms of the lease therefore are essentially inaintamed, when the landlord insists on acquiring additional rent for himself, the terms of the lease have been altered. Such an

88. See Kendall v. Emest Pestana, Inc., 709 P.2d 837, 845 (Cal. 1985) (en banc) (noting that restraints may be allowed to protect property itself and to ensure performance of lease covenants but not to obtain a "better bargaiu"); see also id. at $847-48$ (recognizing that a landlord, by agreeing to a lease, has no claim to possible financial benefits a tenant may gain by alienating the property during the term of the lease). 
alteration would be invalid because it would not involve additional bargaining or consideration.

Examination of the situations in which a landlord is faced with a decision concerning whether to consent to alienation leads to the conclusion that a landlord can withhold consent reasonably when confronted with a silent consent clause only when his investinent is truly in danger of harm. If the landlord's justifications are not based on possible misuse of the premises or characteristics of the proposed substitute lessee that could directly affect the lessee's ability to be a suitable tenant, the withholding of consent is not reasonable.

\section{AN EXAMINATION OF Two COURTS' APPROACHES TO THE CONSENT ClaUSE PROBLEM}

With the foregoing discussion in mind, it is informative to look at the courts' treatment of the consent clause problem. Not only are the state courts taking different paths, but within individual states, the message is not always clear as to what direction the courts are currently pursuing or what justifications they will use to support future decisions. If the law in this area is to become predictable im any given state, not to mention consistent among jurisdictions, a uniform approach to the problein, such as the one suggested in this Note, must be adopted. The decisions of an Ohio court and of a Califorma court illustrate the reigning confusion and concomitant need for reform.

\section{A. Cuyahoga County, Ohio}

Although the highest state courts across the country did not begin to support the minority position that silent consent clauses liave an inherent requirement of reasonableness until the late $1970 \mathrm{~s},{ }^{89}$ a lower court in Ohio supported this position in 1971 in Shaker Building Co. v. Federal Lime \& Stone Co. ${ }^{90}$ Although this was only a inunicipal court decision, the higliest courts of several other states that later supported the reasonableness requirement cited it in support of their own opinions. ${ }^{91}$ Furthermore, this case

89. See, e.g., Homa-Goff Interiors, Inc. v. Cowden, 350 So. 2d 1035 (Ala. 1977).

90. 277 N.E.2d 584 (Shaker Heights, Ohio Mun. C. 1971), rev'd, 1972 WL 20379 (Ohio Ct. App. Mar. 2, 1972), as noted in F \& L Ctr. Co. v. Cunmingham Drug Stores, Inc., 482 N.E.2d 1296, 1299 (Ohio Ct. App. 1984).

91. Homa-Goff, 350 So. 2d at 1037; Kendall, 709 P.2d at 841 ; Funk v. Funk, 633 
and those decided in Cuyahoga County in its aftermath provide a good example of a system in which the law regarding lease ahenation consent clauses is neither clear nor consistent.

In Shaker Building Co., a landlord sued a former tenant for rent after the tenant vacated the premises. The tenant claimed that the landlord should have accepted a proposed assignment to another lessee who wanted to expand in the building in question. Since the assignment had not been accepted, the tenant argued that the landlord had failed to mitigate the damages incurred by the vacating of the lease and that therefore no back rent was owed. In defense, the landlord relied on a clause in the lease agreement that provided that the lessee could not assign the lease without the landlord's consent. ${ }^{92}$ In finding for the defendant, the court held that the lease, having been prepared by the landlord, should be construed when ambiguous strictly against the landlord. Interpreting the clause in light of this principle, the court held that inherent in the consent clause was "representation that an assigninent [was] possible" ${ }^{\prime 93}$ and that if the landlord wanted the right to withhold consent either reasonably or unreasonably, he should have so stated clearly in the lease. The court went on to say that consent could not be withheld unless the landlord's reason related to the unacceptability of the prospective tenant. ${ }^{94}$

After Shaker Building Co., reasonableness in silent consent clauses would seein to have been the law, at least in Cuyahoga County. This was not the case because the decision was soon overturned. ${ }^{95}$ Because the overturning opinion was not published, however, the reasoning of the earher decision was still relied on by soine courts outside Ohio. ${ }^{96}$ Nonetheless, in $F \& L$ Center $v$. Cunningham Drug Stores, Inc., ${ }^{97}$ the opinion that revealed that Shaker Building Co. had been overturned, the Cuyahoga County Court of Appeals publicly rejoined the inajority of states in sup-

P.2d 586, 589 (Idaho 1981); Boss Barbara, Inc. v. Newbill, 638 P.2d 1084, 1086 (N.M. 1982).

92. Shaker Bldg. Co., 277 N.E.2d at 585.

93. Id. at 587.

94. Id.

95. See 1972 WL 20379 (Ohio Ct. App. Mar. 2, 1972). This decision was not reported but was noted by the Cuyahoga County Court of Appeals in F \& L Ctr. Co. v. Cunningham Drug Stores, 482 N.E.2d 1296, 1299 (Ohio Ct. App. 1984), twelve years later.

96. See supra note 91 .

97. 482 N.E.2d 1296 (Ohio Ct. App. 1984). 
porting the idea that consent could be withheld arbitrarily when a lease's consent clause made no express inention of reasonableness. ${ }^{98}$

The law in Cuyahoga County still seems less than settled, however, due to the opinions of one of its appellate judges, Judge Nahra. In his dissent in $F \& L$ Center, Judge Nahra cited the cases supporting the minority position, which requires reasonableness in lease ahenation clauses, discussing at some length the argument that the contract law standard of good faith and fair dealing inplied a standard of "commercial reasonableness." $\mathrm{He}$ echoed the Shaker Building Co. opinion in holding that consent may be withheld only if the tenant proposed by the ahenating lessee would be unacceptable. ${ }^{99}$

Obviously, Judge Nahra's arguments on the subject are not law since they arose in a dissenting opinion, but there is a further indication that the court in Cuyahoga County inight adopt his reasoning. A few years after $F \& L$ Center, then-Chief Judge Nahra wrote the opinion in Sherman v. Carlin. ${ }^{100}$ That case, in which the consent clause was only a tangential issue, involved a decedent's representative who argued that the lease provided that only the decedent could occupy the premises and that it thus terminated at the tinie of death. Chief Judge Nahra stated that the clause in the lease that required the consent of the landlord to assign was not evidence that the decedent would be the only person bound as lessee because "[t]he clause does not prohibit assignment, but only requires the landlord's prior approval. This provision ... acted only to ensure that the tenant's obligations would be performed by [the decedent] or by someone acceptable to the landlord." 101

Whether this position will prevail the next time the silent consent clause issue is raised in the Cuyahoga County courts remains to be seen. $F \& L$ Center was neither distinguished nor

98. Id. at 1300 . The court also mentioned that another clause in the lease at issue, which dealt with major structural changes to the property, did provide that consent could not be unreasonably withheld and that the parties thus could have used the same language with regard to the alienation clause. The court did not rely on this reasoning, however (although it would have been justified in so doing), but instead noted that it made this observation "in passing." Id.

99. Id. at 1300-01 (Nahra, J., dissenting).

100. 546 N.E.2d 433 (Ohio Ct. App. 1988).

101. Id. at 435 (emphasis added). 
inentioned in the Sherman opinion, but the language Judge Nahra used in this later opinion resenibled the language he used in his dissent in the earlier case. Thus, although $F \& L$ Center is still good law, conflicting attitudes are apparent in the caselaw.

\section{B. California}

The situation in California is quite different fron the one in Ohio because the California Supreme Court has consistently upheld the reading of the reasonableness concept into unadorned consent clauses. ${ }^{102}$ Nonetheless, the California decisions have not drawn a clear picture of the issue; instead, they have required analysis of the reasonableness of parties' actions not only with regard to silent clause cases but also in cases in which sucli analysis should not be undertaken.

The leading silent consent clause case in California is Kendall v. Ernest Pestana, Inc. ${ }^{103}$ In Kendall, the plaimtiffs attempted to take an assignment of a lease of hangar space at an airport but were prevented from doing so by the defendant lessor. The defendant argued that under the lease's consent clause, which had no provision for reasonableness, he could withhold consent arbitrarily or to impose higher rent on the proposed assignees. ${ }^{104}$ The court sided witl the plaintiffs and the minority of states, holding that reasonableness of consent was required and that withholding consent to get higher rent that had not been bargained for was not reasonable. ${ }^{105}$ This opinion, in that it supported its holding witl arguments based on freedonı of ahenation and the standard of good faith iniposed on all contracts, is sound. In fact, the court in this case even recognized that generally, parties are free to agree explicitly to restraints on ahenation, ${ }^{106}$ supporting its ruling by noting that the particular consent clause under consideration did not explicitly restrain alienation but rather was anbiguous and thus required a reasonableness inquiry.

102. See supra Section $\Pi(\mathrm{A})$. It should be noted that even in cases in which due-onsale clauses were at issue, the California Supreme Court, in Wellenkamp v. Bank of Am., 582 P.2d 970 (Cal. 1978) (en banc), required that reasonableness be read into the mortgage contracts.

103. 709 P.2d 837 (Cal. 1985) (en banc).

104. Id. at 840 .

105. Id. at 845 .

106. Id. at 844 n.14 (acknowledging that freely negotiated clauses giving absolute discretion over alienation to the landlord may be valid). 
Had there been no cases after Kendall concerning consent clauses in leases, California's approach to the reasonableness issue would be quite clear. Unfortunately, the California Supreine Court was faced with another consent clause case when it was called on to decide Carma Developers (California), Inc. v. Marathon Development California, Inc. ${ }^{107}$ In this case, the lease in question contained two alienation clauses. The first explicitly stated that consent could not be unreasonably withheld. This clause was accompanied by a companion clause that allowed the landlord to terminate the lease on notice of the tenant's intention to sublet or assign. The accompanying provision further allowed tlie landlord to enter into a new lease with the prospective lessee who had been proposed by the original tenant. ${ }^{108}$ When Carnia Developers did try to sublet, their landlord, Maratlion Development, promptly terminated the lease. Carnia sued on the basis of breach of contract and violation of the implied covenant of good faith, and the lower court held that the clause tliat niade no niention of reasonableness-the companion clause-should be read as if it had. ${ }^{109}$

On appeal, the California Supreme Court correctly held that the lease was not anbiguous since it explicitly stated its terms. It was therefore not analogous to the lease in the Kendall case and did not require any reading of reasonableness into the second

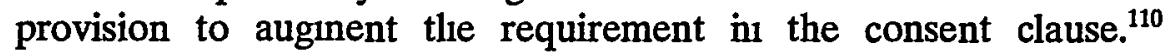
Instead, the court held that the clauses gave the landlord two options when presented with the possibility that the tenant niglit sublet or assign: the landlord could either terminate tlie lease, thereby releasing the tenant from all remaiming obligations, or the landlord could decide not to ternimate, in which case it could not unreasonably withhold consent to alienation. ${ }^{111}$ The court further held that since the landlord acted within the express provisions of the lease, it had not violated the doctrine of good faith. ${ }^{112}$

Had the court stopped at this point, the issue would have been settled. Regrettably, the court had niore to say on the matter. Although acting within the express ternis of a contract is

107. 826 P.2d 710 (Cal. 1992) (en banc).

108. Id. at 713 .

109. Id. at 712 .

110. Id. at 714 .

111. Id.

112. Id. at 729 . 
inherently reasonable and clearly not an abridgement of the goodfaith doctrine, ${ }^{113}$ the court performed the balancing test advocated in Wellenkamp v. Bank of America, ${ }^{114}$ an earher due-on-sale clause case. ${ }^{115}$ This test, similar to the one used in Part III of this Note, ${ }^{116}$ requires a balancing of the justifications for a restraint against the effect of the restraint on alienation. ${ }^{117}$ Using this test, the court found the restraint at issue to be reasonable because it was limited to the duration of the lease, included a forfeiture clause that released the tenant from obligation, and would be invoked, supposedly, only in a rising inarket because a landlord wonld not terminate the lease to re-rent if he could not get more money for doing so. ${ }^{118}$

This analysis turns the whole opinion on its head. Without this analysis, the opinion suggests, soundly, that whenever the lease is explicit, it is out of the realm of the silent consent clause analysis of reasonableness because all actions explicitly allowed for by the lease are inherently reasonable. With the addition of this analysis, however, the opinion inıplies that even when two parties explicitly lay out what is or is not reasonable, the court may disregard their contract and inipose its own determination of reasonableness. Thus, even in cases in which parties have souglit to avoid the silent consent clause debate altogether by being explicit, the court could change the terms of their contract. In a sense, the California court has announced that it will scrutinize all consent clauses as if they were silent consent clauses, regardless of the expressed intent of the parties involved.

Because the Califorma Supreme Court has iniphed that it will look for reasonableness no matter what the situation, even when it is not required by the nature of the contract involved and even

113. The court obviously could not hold that the defendant had acted in bad faith for domg exactly what the contract said it could do. See supra text accompanying notes $62-64$.

114. 582 P.2d 970 (Cal. 1978) (en banc).

115. Carma, 826 P.2d at 716; see Wellenkamp, 582 P.2d at 973.

116. The fact that a similar test was used in a due-on-sale clause case is irrelevant. The problein with those cases that advocated reading reasonableness into due-on-sale clauses was not the particular balancing test used to determine what was reasouable, but rather that any balancing was done at all. See supra Section I(A). Thus, although a balancing test is valid for determining reasonableness, its use should be confined to cases in whiclt there actually are unadorned consent clauses. Carma was not such a case.

117. Carma, 826 P.2d at 716-17 (citing Wellenkamp, 582 P.2d at 973).

118. Id. at 719 . 
when what is reasonable has already been explicitly defined, states following the majority rule in silent consent clause cases may be loathe to follow California's lead in adopting the minority opinion. After all, the California Supreme Court's approach is confusing, at times imconsistent, and, as a result, hard to apply. Thus, states following the majority rule, despite their faulty reasoning, may continue to eschew the invocation of reasonableness into silent consent clauses simply because such an approach seems less difficult. This result would be unfortunate, particularly because the minority approacl, when used correctly, is not complicated, as illustrated by the test proposed in this Note.

\section{CONCLUSION}

Although silent consent clauses seem innocuous in that they merely require a tenant who wants to sublet or assign his lease to ask the landlord before doing so, they have spawned decades of debate among and within states. Due to their pervasiveness, they will continue to promote confusion if state courts or legislatures do not take action to promote uniform treatinent. ${ }^{119}$

The best way to promote sucl uniformity would be to require the reading of reasonableness into all silent consent clauses. Analysis of the concept of freedom of alienation, as well as generally accepted contract interpretation principles, demonstrates that both real property and contract laws support this approacl. In addition, such an approach would end the confusion of state courts that are currently unable to articulate a clear preference for one view over the other.

Unfortunately, unlike the due-on-sale clause problem that involved the activities of institutional lenders that could be resolved by Congress under federal banking laws, the silent consent clause problem concerns property and contract law issues traditionally reserved to the states. Therefore, it is the responsibihty of the state courts (or legislatures) to look beyond both the entrenched majority rule and the confusing attempts by some courts to adopt the minority rule to the basic rules of real property law and contract interpretation. The states can then adopt a uniforni,

119. See, e.g., TEX. PROP. CODE ANN. $\S 91.005$ (West 1984) (prohibiting tenants from subletting without landlord's consent; Young v. De La Garza, 368 S.W.2d 667, 670 (Tex. Civ. App. 1963) (noting that TEX. REv. CIV. STAT. art. 5237 (the statutory precursor to $\S 91.005$ ) "is made a part of every lease contract [in Texas] by operation of law"). 
stable rule of silent consent clause application based on the concept of reasonableness. 
